\title{
HYBRID LEARNING: MODEL PEMBELAJARAN PADA MASA PANDEMI DI SD NEGERI BUNGURASIH WARU SIDOARJO
}

\author{
M. Makhin \\ SD Negeri Bungurasih Waru Sidoarjo \\ Email:muh.makhin@gmail.com
}

Dikirim:27 Mei 2021 | Direvisi: 15 Juni 2021 | Dipublikasikan: 31 Juli 2021

\begin{abstract}
Abstraksi: Efek Covid-19 yang memiliki dampak luar biasa bagi seluruh sektor kehidupan, sehingga semua kebijakan pemerintah diarahkan pada pembatasan kegiatan yang harus diikuti oleh seluruh kementerian tak terkecuali pada Kementerian Pendidikan dan Kebudayaan (Kemendikbud) yakni pembatasan kegiatan tatap muka di lembaga pendidikan dengan melakukan proses belajar dari rumah (BDR). Pembelajaran daring yang telah dilaksanakan dengan waktu yang relatif lama ini mulai dikhawatirkan berpengaruh negatif bagi psikososial peserta didik, sehingga perlu alternatif solusi untuk meminimalisir pengaruh negatif tersebut. Inovasi yang dilakukan guru yakni menerapkan Hybrid Learning demi memaksimalkan pembelajaran yang dilakukan selama pandemi Covid-19 ini. Penelitian ini merupakan penelitian kualitatif deskriptif dengan tujuan mendeskripsikan Hybrid Learning yang diimplementasikan di SD Negeri Bungurasih Waru Sidoarjo dan problematika yang dialami serta solusinya. Hasil penelitian ini, terdapat beberapa tahapan yang dilakukan guru dalam implementasi Hybrid Learning antara lain: pertama, tahap perencanaan. Pada tahap ini dilakukan beberapa hal yakni: sosialisasi pembelajaran jarak jauh kepada wali murid, pembentukan paguyuban setiap paralel kelas, pembagian kelompok kecil siswa, pembuatan perangkat pembelajaran; kedua, tahap implementasi. Pada tahapan ini Hybrid Learning dilakukan dengan kombinasi pembelajaran dalam jaringan (daring) dan pembelajaran tatap muka yang dilaksanakan secara berkelompok di rumah peserta didik; ketiga, tahapan evaluasi atau penilaian dilakukan dengan pemberian soal tes dan non tes. Problem pada pembelajaran Hybrid antara lain: kemampuan literasi teknologi yang belum maksimal; terbatasnya waktu, kurang adanya kesadaran dari peserta didik dan sebagian wali murid untuk memaksimalkan pendampingan belajarnya. Solusi yang diberikan yakni dengan memberikan pendampingan yang lebih maksimal terkait literasi digital sehingga pembelajaran yang dilaksanakan kedepannya lebih maksimal.
\end{abstract}

Kata kunci: Hybrid learning; inovasi pendidikan; blended learning.

\section{Pendahuluan}

Semenjak World Health Organization (WHO) mengumumkan status pandemi covid 19 yakni sekitar awal tahun 2020, untuk merespon itu, maka semua kementerian melakukan pembatasan kegiatannya termasuk kegiatan belajar mengajar di sekolah. Kemendikbud dalam rangka membatasi penyebaran virus Covid 19 mengeluarkan kebijakan belajar dari rumah (BDR) secara daring dan meniadakan proses belajar mengajar tatap muka yang biasanya dilaksanakan di lembaga pendidikan formal. Namun seiring perkembangan penyebaran Covid 19 yang mulai menurun, pada tahun 2021 pemerintah mengeluarkan kebijakan baru tentang prosedur pembelajaran tatap muka. ${ }^{1}$ Pemerintah melalui kemendikbud membuka kemungkinan pembelajaran tatap muka yang maksimal akan mulai dilakukan pada awal tahun ajaran baru 2021-2022, dengan tetap melihat perkembangan situasi dan

${ }^{1}$ Ahmad Noval and L K Nuryani, "Manajemen Pembelajaran Berbasis Blended Learning Pada Masa Pandemi Covid19 (Studi Kasus Di MAS YPP Jamanis Parigi Dan MAN 1 Pangandaran)," Jurnal Isema: Islamic Educational Management, Vol. 5, no. 2 (December 31, 2020): 202, accessed February 8, 2021, http://journal.uinsgd.ac.id/index.php/isema. 


\section{Makhin}

kondisi penularan virus Covid 19 serta dengan menerapkan protokol kesehatan yang sangat ketat. Kebijakan tersebut sebagai tindak lanjut dari hasil evaluasi selama penerapan kebijakan Pembelajaran Jarak Jauh (PJJ) sepanjang pandemi Covid 19. ${ }^{2}$

Peralihan kegiatan belajar mengajar yang biasanya dilakukan secara tatap muka kepada pembelajaran secara online atau daring ini memaksa berbagai pihak untuk mengikuti alur yang ada sebagaimana kebijakan pemerintah, agar pembelajaran di lembaga pendidikan tetap dapat berjalan dengan baik, serta dapat dilakukan kapan saja dan dimana saja tentunya dengan dengan memanfaatkan kemajuan teknologi informasi dan komunikasi, dalam hal ini menggunakan berbagai platform yang telah ada, misalnya dengan memanfaatkan sosial media (sosmed) dan platform yang telah disediakan oleh Kementerian Pendidikan dan Kebudayaan dan Kementerian Agama untuk menunjang pembelajaran online atau e-learning. ${ }^{3}$

Pelaksanaan pembelajaran jarak jauh (PJJ) yang dilakukan secara daring dari awal pandemi hingga saat ini, dikhawatirkan akan berpengaruh negatif pada aspek psikososial peserta didik, ${ }^{4}$ sehingga perlu adanya perubahan terkait teknis pembelajaran daring yang sebelumnya murni dalam jaringan sehingga dilakukan kombinasi pembelajaran secara luring (luar jaringan) atau offline (tatap muka) atau lebih dikenal dengan istilah Hybrid Learning, yakni model pembelajaran yang mengintegrasikan inovasi dan kemajuan teknologi melalui sistem online learning dengan interaksi dan partisipasi dari model pembelajaran tradisional. ${ }^{5}$ Sistem pembelajaran ini juga menggabungkan dua macam pilihan siapa yang akan berperan utama yakni apakah pelajar ataukah pengajar. Sehingga pada umumnya pada tahapan awal menerapkan peran pengajar lebih dominan dan ketika telah berjalan baik, maka diubah pada peran siswa yang lebih dominan (student center).

Beberapa model Hybrid Learning yang berkembang pada kurun waktu sekarang merupakan penggabungan dari satu atau lebih dimensi berikut: pertama, pembelajaran Face to Face, yakni pembelajaran yang dilaksanakan secara tatap muka di kelas, praktik yang dilaksanakan di Laboratorium, aktifitas pembelajarannya meliputi penyampaian materi, diskusi dan presentasi, latian dan evaluasi pembelajaran atau ujian; kedua, Synchronous Vitual Collaboration, yakni desain pembelajaran kolaboratif yang mana pelibatan interaksi antara pendidik dan tenaga kependidikan dilakukan pada saat yang sama. Aktivitas pembelajarannya memanfaatkan aplikasi, misalnya Instan Messaging (IM) atau aplikasi chat. uran (evaluasi); Ketiga, pembelajaran dengan Asynchronous Virtual Collaboration, yang mana merupakan desain pembelajaran yang melibatkan interaksi antara guru dan peserta didik. Pelaksanaannya disampaikan pada waktu yang berbeda failitas yang digunakan dalam aktifitas belajarnya adalah online discussion board atau forum diskusi dan email; keempat, model pembelajaaran Self Pace Asynchronous, merupakan model pembelajaran yang dilakukan peserta didik dalam waktu yang berlaianan dan mandiri, materi diberikan dalam bentuk buku atau modul, latian soal atau evaluasi pembelajaran dilakukan secara online. ${ }^{6}$

\footnotetext{
2 Oce Payung Limbong, Witarsa Tambunan, and Mesta Limbong, "Kesiapan Pelaksanaan Pembelajaran Tatap Muka Di SMK Negeri 2 Toraja Utara Pada Masa Pandemi," Jurnal Manajemen Pendidikan 10, no. 1 (2021): 38.

3 Dian Misesani, "Peningkatan Kemampuan Guru Dalam Pemanfaatan Google Classroom Sebagai Media Pembelajaran Online," JMM Jurnal Masyarakat Madani) 5, no. 4 (2021): 1641, http://journal.ummat.ac.id/index.php/jmm.

${ }^{4}$ Henri Yazid and Neviyarni, "Pengaruh Pembelajaran Daring Terhadap Psikologi Siswa Akibat Covid-19," Jurnal Human Care 6, no. 1 (2021): 208.

${ }^{5}$ Heny Hendrayati and Budhi Pamungkas, "Implementasi Model Hybrid Learning Pada Proses Pembelajaran Mata Kuliah Statistika II Di Prodi Manajemen FPEB UPI,” Jurnal Penelitian Pendidikan 13, no. 2 (2016): 181.

${ }^{6}$ Ibid., 182.
} 
Salah satu sekolah yang mengimplementasikan pembelajaran Hybrid Learning adalah SDN Bungurasih Waru Sidoarjo. Implementasi ini dimaksudkan sebagai langkah preventif guna untuk mengatasi kejenuhan peserta didik dalam pembelajaran daring, yang mana selama ini dilaksanakan secara full semenjak awal diberlakukannya pembelajaran jarak jauh oleh kemendikbud hingga awal tahun 2021. Inovasi dilakukan oleh guru kelas VA, VB dan VC, yakni oleh Bapak M. Makhin, Ibu Emy dan Ibu Rosy dengan memanfaatkan platform yang telah disediakan, misalnya melalui platform guru belajar Kemendikbud, Aplikasi WhatsApp, Classroom Goggle dan Aplikasi E-Learning yang lain. Oleh karena itu dalam artikel ini mencoba mennggali dan mendeskripsikan bagaimana implementasi dari Hybrid Learning di SD Negeri Bungurasih Waru Sidoarjo.

\section{Metode Penelitiaan}

Metode penelitian kualitatif dan analisis deskriptif yang dipakai dalam penelitian ini. Hal ini dilakukan untuk menggali bagaimana fenomena yang ada pada objek penelitian secara holistik dan mendalam, sehingga data yang diperoleh lebih bermakna dari informan di lapangan. Peneliti mengumpulkan data dengan wawancara, observasi dan dokumentasi dengan mengikuti prosedur penelitian yang telah ditentukan. Penelitian ini dilakukan di SD Negeri Bungurasih Waru Sidoarjo dengan rentang waktu 6 bulan mulai Januari sampai Juni 2021, dengan partisipan kepala sekolah, guru kelas $\mathrm{V}$, serta perwakilan wali murid. Data yang diperoleh dari lapangan dianalisis dengan model Miles Huberman, yakni reduksi data, penyajian data, dan conclusion drawing/verification. Dari analisis data tersebut saling berkaitan satu sama lain, keabsahan data dilakukan dengan triangulasi data. $^{7}$

\section{Hasil dan Pembahasan}

Hasil penelitian ini diperoleh melalui proses wawancara, observasi dan dokumentasi data di lapangan tentang Implementasi Hybrid Learning pada pembelajaran di kelas V SD Negeri Bungurasih Waru Sidoarjo, Berikut paparan data dan pembahasannya:

1. Implementasi Hybrid Learning Pada Pembelajaran di Kelas V SDN Bungurasih Waru Sidoarjo

Adanya pandemi yang masih belum usai, mengharuskan adanya perubahan metode pembelajaran yang sebelumnya dilakukan secara klasikal dengan tatap muka di kelas, beralih pada pembelajaran Dalam Jaringan (Daring) dengan tetap mengikuti kebijakan pemerintah, dalam hal ini Kementerian Pendidikan dan Kebudayaan. Sebagai sekolah negeri yang terletak di perbatasan Surabaya dan Sidoarjo yang mana secara geografis terletak di kota dan tentunya selalu dimonitoring betul oleh pengawas Koordinator Wilayah (Korwil) Dinas Pendidikan Kecamatan Waru sehingga segala pelaksanaan kegiatan belajar mengajar di SD Negeri Bungurasih Kecamatan Waru Kabupaten Sidoarjo begitu dipantau apalagi proses pembelajaran pada masa pandemi Covid-19 ini. Implementasi diartikan sebagai sebuah pelaksanaan atau penerapan dari sesuatu yang telah direncanakan dengan baik. ${ }^{8}$ Pada implementasi ini terdiri dalam tiga tahapan yakni, perencanaan, implementasi dan evaluasi. Berikut ini uraiannya.

\footnotetext{
${ }^{7}$ Kurnia Dwi Setyaningsih, Karma Iswasta Eka, and Badarudin Badarudin, “Analisis Pelaksanaan Pembelajaran Jarak Jauh Di SD Negeri Karangrena 03," Jurnal Riset Pendidikan Dasar (JRPD) 2, no. 1 (2021): 5.

8 Faridatul Kibtiyah Zaini, Anwar Sa'dullah, and Muhammad Sulistiono, "Implementasi Hybrid Learning Dalam Pembelajaran Pendidikan Agama Islam Di SMAN 2 Malang," VICRATINA: Jurnal Pendidikan Islam 6, no. 4 (2021): 106. Baca juga dalam M. Joko Susilo, Kurikulum Tingkat Satuan Pendidikan (Yogyakarta: Pustaka Pelajar, 2007), 174.
} 
a. Tahapan Perencanaan Pembelajaran dengan Hybrid Learning di SD Negeri Bungurasih Waru Sidoarjo.

Sebagaimana kompetensi yang wajib dikuasai oleh guru yakni kompetensi pedagogik guru, maka guru mampu dalam merencanakan dan mengimplementasikan serta mengevalusi pembelajaran yang diampunya, ${ }^{9}$ maka dalam implementasi pembelajaran Hybrid Learning khususnya tahap perencanaan ini yang dilakukan oleh guru kelas yakni dengan dua perencanaan, yakni perencanaan pembelajaran secara luring dan perencanaan pembelajaran secara daring. Dokumen perencanaan secara luring dan daring disusun oelh guru secara bertahap dan paralel baik dari kelas VA, VB dan VC yang mana diampu oleh Bapak M. Makhin, Ibu, Emy dan Ibu Rosy dan sebelum memulai kegiatan pembelajaran guru menyusun RPP satu lembar secara bersama, dengan tetap berpedoman pada buku pedoman dari kemendikbud, yang mana RPP harus mengintegrasikan pendidikan karakter, Literasi, HOTS, dan Muatan 4C. ${ }^{10}$ begitupun juga sebagaimana arahan dari Ibu kepala sekolah yakni, Sri Indarti yang sering disampaikan dalam rapat dinas baik yang dilakukan secara luring di sekolah, ataupun dilakukan secara daring lewat aplikasi Zoom Meeting.

Pada masa pandemi ini, khusus pada implementasi pembelajaran luring, selain mempersiapkan dokumen perangkat pembelajaran sebagaimana dijelaskan di atas, pada tataran pelaksanaan pembelajaran luring ini dilakukan dengan membagi siswa menjadi beberapa kelompok kecil yang terdiri dari 5-7 siswa dan pelasanaan pembelajarannya melalui kunjungan ke rumah siswa. secara teknis; siswa dibagi menjadi beberapa kelompok kecil kemudian ketika pelaksanaan, maka siswa berkumpul di salah satu rumah paguyuban wali murid yang telah disepakati sebelumnya. Pelaksanaan pembelajaran dibagi dalam dua sesi, sesi pertama dimulai dari jam 7-9 dan sesi kedua mulai jam 10-12 dengan tetap berpatokan pada protokol kesehatan yang ketat. Media yang digunakan dalam mengkomunikasikan planing pembelajaran dilakukan dengan Aplikasi WhatsApp.

Terkait perencanaan pembelajaran dalam jaringan (daring), yakni dengan menggunakan berbagai macam platform, meliputi WhatsApp, Classroom Google, Google Meet, Zoom Meeting, Guru Belajar Kemendikbud, Aplikasi Ruang Guru dan Genius. Tahapan perencanaan ini dilakukan oleh guru dengan memberikan arahan terkait teknis yang akan dilakukan dalam proses pembelajaran secara daring atau dikenal dengan istilah lain yakni Blended Learning, ${ }^{11}$ yang mana pembelajaran dengan model ini bisa menjadi solusi alternatif pada masa post pandemic. Sebgaimana dijelaskan dalam jurnal yang ditulis oleh Seriwati Ginting, Miki Tjandra dan Elizabeth Wianto ${ }^{12}$

\footnotetext{
9 Yovi Anggi Lestari and Margaretha Purwanti, "Hubungan Kompetensi Pedagogik, Profesional, Sosial, Dan Kepribadian Pada Guru Sekolah Non Formal X,” JURNAL KEPENDIDIKAN 2, no. 1 (2018): 199-200.

${ }^{10}$ Fatimah Fatimah et al., "Analisis PPK, Literasi, 4c Dan HOTS Pada Silabus Dan RPP Mata Pelajaran Fikih," Quality 8, no. 1 (2020): 165-185.

${ }^{11}$ Dwi Indah Nursita, "Penerapan Blanded Learning Pada Siswa Sekolah Dasar: Sebagai Upaya Meningkatkan Kualitas Pembelajaran Di Masa Pandemi Covid ...," SALIMA: Jurnal Pendidikan Guru MI 1, no. 1 (2021): 1-12, http://ejurnal.staiattanwir.ac.id/index.php/jpgmi/article/view/52. Baca juga terkait pembelajarn Hybrid learning pada mata pelajaran lain dalam Fajar Hidayatullah and Khoirul Anwar, "Hybrid Learning Dalam Pembelajaran Pendidikan Jasmani Sekolah Dasar Dan Menengah Maupun Pendidikan Olahraga Perguruan Tinggi," Prosiding SENOPATI (Seminar Olahraga Pendidikan dalam Teknologi dan Inovasi) 1, no. 1 (2020): 1-7, http://publikasi.stkippgribkl.ac.id/index.php/senopati/article/view/502/359.

12 Seriwati Ginting, Miki Tjandra, and Elizabeth Wianto, "Blended Learning: Post Pandemic Solutions," Aksara: Jurnal Ilmu Pendidikan Nonformal 7, no. 2 (2021): 425-438.
} 
b. Tahapan Implementasi/Penerapan Model Pembelajaran Hybrid Learning di SD Negeri Bungurasih Waru Sidoarjo.

Tahapan ini sebagai bagian dari tindak lanjut dari tahapan pelasanaan yang telah dijelaskan sebelumnya. Penulis membagi tahapan ini menjadi beberapa cakupan, antara lain: durasi proses kegiatan belajar mengajar, platform yang digunakan, setrategi, metode, media dan bahan ajar yang dipilih guru dalam proses pembelajaran. Baik secara luring maupun daring. Pelaksanaan pembelajaran daring dilaksanakan setiap hari dari hari senin hingga sabtu, namun tidak menutup kemungkinan hari ahadpun terkadang masih terjadi komunikasi dengan siswa dan wali murid melalui aplikasi whats App terkait arahan-arahan pembelajaran yang dilakukan pada pertemuan selanjutnya. Berbagai platform aplikasi digunakan dalam pembelajaran daring ini, misalnya classroom google, meet google, aplikasi zenius, ruang guru dan aplikasi lain yang telah disediakan oleh kementerian pendidikan dan kebudayaan. Pemilihan aplikasi sangat mempengaruhi kegiatan pembelajaran dalam jaringan, semua dilakukan demi terwujudnya interaksi yang lebih baik dengan peserta didik dengan harapan pembelajaran yang dilakukan bisa berkualitas dan menyenangkan.

Adapun pembelajaran luring dilakukan dengan sistem kelompok atau diskusi kecil yang dilaksanakan secara bergiliran, dengan lokasi yang berbeda yakni di rumah siswa yang mana pada tahap perencanaan telah dibagi beberapa kelompok. tentunya pembelajaran luring ini tetap menerapkan protokol kesehatan yang ketat pula. Durasi dari setiap pemblajaran luring perkelompok adalah 120 menit dilakukan satu minggu 3 kali sebagai sambungan atau tindak lanjut dari pembelajaran daring yang telah dilakukan. bahan ajar yang digunakan dalam pembelajaran daring menggunakan modul, materi yang diselipkan di Google Form yang diberi oleh guru untuk peserta didik atau memberikan link video materi untuk dipelajari oleh peserta didik di rumah. sedangkan bahan ajar yang digunakan dalam pembelajaran luring menggunakan buku paket dan buku lembar kerja siswa (LKS) yang sudah disediakan oleh sekolah. Selanjutnya keempat, metode pembelajaran yang digunakan oleh guru dalam kegiatan proses belajar mengajar yaitu memakai metode ceramah, penugasan, dan latihan, driil, dan tanya jawab.

c. Tahapan evaluasi atau penilaian pembelajaran.

Tahap evaluasi pembelajaran yang diimplementasikan oleh guru kelas 5 dalam proses evaluasi atau penilaian pembelajaran bybrid Learning di SDN Bungurasih Waru Sidoarjo sebagaimana yang dianjurkan dalam kurikulum 2013, meliputi: (1) Penilaian Otentik, (2) Penilaian Diri, (3) Penilaian Proyek, (4) Ulangan Harian, (5) Ulangan Tengah Semester dan Ulangan Akhir Semester. Adapun instrumen yang digunakan dalam penilaian kompetensi sikap, pengetahuan, dan keterampilan, melalui: (1) Penilaian kompetensi sikap, dilakukan melaui observasi, penilaian diri, penilaian teman sejawat, jurnal; (2) Penilaian kompetensi pengetahuan, dilakukan melaui tes tulis, tes lisan, penugasan; (3) Penilaian kompetensi keterampilan, diperoleh melaui tes praktik, proyek dan portofolio. ${ }^{13}$

13 Penelitian lain yang dapat dinilai memiliki tahapan yang sama terkait evaluasi dalam pembelajaran kurikulum 2013 baik pada kompetensi sikap, pengetahuan dan keterampilan lebih lengkapnya baca Muslih, Muslih. "Pembelajaran AyatAyat Kauniyah Di SMA Trensains 2 Tebuireng Jombang,” ISLAMICA: Jurnal Studi Keislaman 2, no. 2 (2018): 474, http://islamica.uinsby.ac.id/index.php/islamica/article/view/427. 
2. Faktor Penghambat dan Pendukung dalam Implementasi Hybrid Learning Pada Pembelajaran di Kelas V SDN Bungurasih Waru Sidoarjo

Tidak dipungkiri lagi bahwa dalam proses pembelajaran pada lembaga pendidikan tentunya proses kegiatan belajar mengajar yang diselenggarakan tidak lepas dari kekurangan, begitu pula implementasi pembelajaran dengan bybrid learning oleh guru kelas V di SDN Bungurasih Waru Siodarjo, untuk itu dari hasil observasi dan wawancara penulis memetakan terkait faktor penghambat dan pendukung dalam pembelajaran bybrid learning, berikut uraiannya:

a. Faktor Penghambat Implementasi Hybrid Learning pada Pembelajaran di Kelas V pada Masa Pandemi di SDN Bungurasih Waru Sidoarjo

1) Kompetensi guru

Implementasi bybrid learning pada pembelajaran di kelas V di SDN Bungurasih Waru Sidoarjo, kurang begitu maksimal dikarenakan faktor kemampuan guru dalam mengoperasikan aplikasi-aplikasi yang akan digunakan dalam pembelajaran kepada peserta didiknya. Selain itu kemampuan guru dalam melakukan evaluasi atau pengukuran terhadap capaian kemampuan peserta didik dalam pembejaran bybrid learning masih kurang maksimal. Sebagaimana yang diutarakan oleh Cahyanto dalam jurnalnya, bahwa kendala yang pastinya akan dialami oleh guru dalam pembelajaran daring adalah kesulitan dalam memantau dan mengevaluasi hasil belajar dari peserta didik. $^{14}$

2) Orang Tua

Pembelajaran jarah jauk (PJJ) yang dilaksankan mulai awal 2019 sebagai dampak dari penyebaran virus Covid ke Indonesia, memberikan akibat yang luar biasa. Dikarenakan sekitar 2 tahun pembelajaran daring yang dilakukan memberikan efek tersendiri yakni adanya rasa jenuh yang dialami oleh orang tua murid pada proses pembelajaran yang dilakukan oleh putra putrinya. Butuh perhatian tersendiri terhadap anak-anak ketika melaksanakan proses pembelajaran daring, di sisi lain orang tua khususnya ibu harus juga membagi waktu untuk mendampingi belajar dan juga untuk bekerja. Sehingga tidak dapat dihindari lagi jika ada orang tua yang kurang maksimal dalam pembelajaran daring dan terkesan cuek karena kesibukan kerja. Banyak dari orang tua berharap agar segera dilaksanakan pembelajaran tatap muka kepada sekolah dan pemerintah, ada kekhawatiran juga akan terjadi ketergantungan siswa terhadap gadget di samping itu juga terkait minimnya paketan data internet untuk sambungan gadget dengan internet.

3) Siswa

Pembelajaran jarak jauh telah memberikan dampak tersendiri bagi psikologis siswa yakni ketergantungan gadget hingga terkadang juga di salah gunakan, misalnya waktunya pembelajaran daring, namun digunakan untuk game online, sehingga menjadikan tidak maksimal proses daringnya, jika tanpa diawasi oleh orang tua. Di sisi lain keterbatasan akses siswa dengan alat-alat teknologi dan komunikasi menjadikan efek tersendiri bagi keberlangsung proses pembelajaran daring yang dilakukan oleh guru.

14 Zaini, Sa'dullah, and Sulistiono, "Implementasi Hybrid Learning Dalam Pembelajaran Pendidikan Agama Islam Di SMAN 2 Malang," 108. 
4) Aplikasi

Faktor lain yang menjadi penghambat dalam pembelajaran Hybrid Learning di SDN Bungurasih Waru Sidoarjo adalah aplikasi yang berfungsi sebagai media pembelajaran jarak jauh terkadang mengalami eror, ketika eror terjadi pada aplikasi, misalnya: zoom meeting, meet google, raung guru dan yang lain menjadikan terkendalanya proses pembelajaran yang berlangsung, sehingga perlu berjaga-jaga dan menyiapkan alternatif lain agar pembelajaran tetap berjalan dengan baik dan efesien.

b. Faktor Pendukung Implementasi Hybrid Learning pada Pembelajaran di Kelas V pada Masa Pandemi di SDN Bungurasih Waru Sidoarjo

1) Guru

Implementasi Hybrid Learning pada pembelajaran oleh guru kelas V di SDN Bungurasih memberikan pengaruh positif tersendiri bagi guru-guru. kebijakan yang telah diambil oleh kepala sekolah untuk pelaksanaan pembelajaran di era pandemi ini memberikan kesadaran perubahan pola pikir untuk selalu belajar khususnya terkait penggunaan aplikasi meeting, baik itu zoom meting, google meet, zenius, dan yang lain sebagainya. Dari sini, dapat diambil sebuah kesimpulan bahwa untuk merubah pola pikir pendidik dan tenaga kependidikan perlu adanya aturan atau kebijakan baru yang diberlakukan, sehingga walau dengan agak terpaksa para guru akan dengan sendirinya belajar atau menambah kompetensinya tentang sistem baru yang harus diimplementasikan dalam pembelajaran.

2) Orang Tua

Konteks tugas orang tua dalam mendidik anak-anaknya tidak hanya terbatas pada waktu tertentu, namun tugas mendidik orang tua adalah selama 24 jam dan secara holistk melingkupi aspek spiritual, sosial, pengetahuan dan keterampilan. Dukungan orang tua begitu penting adanya dan sangat mempengaruhi pada pola perkembangan kehidupan anak. Terkait orang tua di sini bisa menjadi kompenen penghambat dan bisa pula komponen orang tua ini masuk pada faktor pendukung, karena antara orang tua dan siswa merupakan satu kesatuan yang saling terkait. Pada konteks ini, dukungan orang tua yang luar biasa menjadi faktor tersendiri dalam memperlancar proses pembelajaran bybrid learning pada kelas V SDN Bungurasih Waru Sidoarjo. Tanpa dukungan dari orang tua seorang anak tidak akan sukses. Dukungan atau support yang ditunjukkan oleh orang tua kepada anak sangat membantu dalam proses belajar mereka terutama pada saat pandemi seperti ini. Mereka lebih banyak belajar di rumah sehingga orang tua mengetahui bagaimana proses belajar tersebut berjalan dan orang tua dapat mengontrol dengan baik.

3) Siswa

Selain faktor pendukung muncul dari guru dan orang tua, siswa juga memiliki faktor pendukung untuk mendukung proses pembelajaran tersebut berjalan dengan baik dan lancar. Faktor pendukung yang dimiliki oleh siswa adalah dengan adanya bentuk kedisiplinan ketika belajar baik melalui daring ataupun luring. Sikap kerja sama dengan teman lainnya pun sangat berpengaruh untuk berjalannya kegiatan proses belajar tersebut. Minat belajar siswa dalam kegiatan proses pembelajaran utamanya dalam pembelajaran pada saat ini yang menggunakan sistem hybrid learning atau pembelajaran secara daring dan luring yaitu setiap belajar tidak dibatasi dari segi apapun karena dapat 
belajar setiap saat dan dimanapun karena materi yang dijelaskan oleh guru dapat di pelajari kapan saja.

4) Aplikasi

Adanya aplikasi, secara tinjauan media akan sangat membantu proses implementasi sebuah kebijakan, khususnya pada pembelajaran. Walaupun di satu sisi secara teknis bisa jadi menjadi penghambat. Adanya aplikasi seperti google meet dan zoom dan aplikasi penunjang lain sangat membantu mempermudah proses pembelajaran yang dilaksankan melalui jaringan (daring). Tanpa itu dapat dipastikan proses pembelajaran jarak jauh yang diimplementasikan pihak sekolah akan sangat menghambat. Proses pembelajaran yang menggunakan aplikasi seperti aplikasi yang digunakan oleh sekolah berupa E-Learning bukan hanya berisi perintah tugas atau ulangan harian untuk peserta didik akan tetapi fungsinya juga sangat praktis apalagi dalam pembelajaran di era abad 21 seperti sekarang ini.

\section{Kesimpulan}

Implementasi bybrid learning dalam pembelajaran kelas V di SDN Bungurasih Waru Sidoarjo terdapat beberapa tahapan yang dilakukan oleh guru antara lain; perencanaan, pelaksanaan serta evaluasi penilaian pembelajaran. Pada perencanaan pembelajaran secara luring yang dilakukan oleh pendidik adalah dengan mempersiapkan perangkat pembelajaran, misalnya RPP satu lembar dan yang lainnya. Sedangkan perencanaan pembelajaran daring yakni dengan memberikan arahan kepada peserta didik melalui aplikasi atau e-learning. Implementasi pembelajaran dilakukan dengan beberapa langkah: membagi siswa kedalam kelompok kecil dan membagi scedule pelaksanaan pembelajaran luring disetiap kelompok ajar. Durasi yang ditentukan baik pembelajaran daring maupun luring adalah 60 menit, aplikasi yang digunakan yaitu E-Learning, Zoom, Google Meet, Google Classroom, Whatsapp Groub dan lain sebagainya. Sedangkan pada tahap penilaian dilihat melalui keaktifan dan respon peserta didik dalam mengikuti pembelajaran serta melalui penilaian tugas dan ulangan harian.

Terdapat empat faktor penghambat dan pendukung implementasi hybrid learning diantaranya adalah dari guru, orang tua, siswa, dan aplikasi. Dengan adanya ketidaksiapan seorang guru dalam memulai pembelajaran maka guru diharuskan menguasai teknologi dengan baik, memberikan paket data yang mencukupi, memiliki sinyal yang stabil, orang tua memberikan semangat dan dukungan kepada anak agar anak tersebut selalu giat dalam belajar. siswa juga diharapkan untuk selalu memahami materi yang diberikan oleh guru.

\section{Daftar Kepustakaan}

Fatimah, Fatimah, Muhtar Tajuddin, Muhammad Ilyas, and Abdul Majid. "Analisis PPK, Literasi, 4c Dan HOTS Pada Silabus Dan RPP Mata Pelajaran Fikih.” Quality 8, no. 1 (2020): 165.

Ginting, Seriwati, Miki Tjandra, and Elizabeth Wianto. "Blended Learning: Post Pandemic Solutions." Aksara: Jurnal Ilmu Pendidikan Nonformal 7, no. 2 (2021): 425.

Hendrayati, Heny, and Budhi Pamungkas. "Implementasi Model Hybrid Learning Pada Proses Pembelajaran Mata Kuliah Statistika II Di Prodi Manajemen FPEB UPI.” Jurnal Penelitian Pendidikan 13, no. 2 (2016). 
Hidayatullah, Fajar, and Khoirul Anwar. "Hybrid Learning Dalam Pembelajaran Pendidikan Jasmani Sekolah Dasar Dan Menengah Maupun Pendidikan Olahraga Perguruan Tinggi." Prosiding SENOPATI (Seminar Olabraga Pendidikan dalam Teknologi dan Inovasi) 1, no. 1 (2020): 1-7. http://publikasi.stkippgri-bkl.ac.id/index.php/senopati/article/view/502/359.

Lestari, Yovi Anggi, and Margaretha Purwanti. "Hubungan Kompetensi Pedagogik, Profesional, Sosial, Dan Kepribadian Pada Guru Sekolah Non Formal X.” JURNAL KEPENDIDIKAN 2, no. 1 (2018): 197-208.

Limbong, Oce Payung, Witarsa Tambunan, and Mesta Limbong. "Kesiapan Pelaksanaan Pembelajaran Tatap Muka Di SMK Negeri 2 Toraja Utara Pada Masa Pandemi." Jurnal Manajemen Pendidikan 10, no. 1 (2021): 37-45.

Misesani, Dian. "Peningkatan Kemampuan Guru Dalam Pemanfaatan Google Classroom Sebagai Media Pembelajaran Online.” JMM (Jurnal Masyarakat Madani) 5, no. 4 (2021): 1640-1652. http://journal.ummat.ac.id/index.php/jmm.

Muslih, Muslih. "Pembelajaran Ayat-Ayat Kauniyah Di SMA Trensains 2 Tebuireng Jombang." ISLAMICA: Jurnal Studi Keislaman 2, no. 2 (2018): 455-480. http://islamica.uinsby.ac.id/index.php/islamica/article/view/427.

Noval, Ahmad, and Lilik Kholishoh Nuryani. "Manajemen Pembelajaran Berbasis Blended Learning Pada Masa Pandemi Covid-19 (Studi Kasus Di MAS YPP Jamanis Parigi Dan MAN 1 Pangandaran)." Jumal Isema: Islamic Educational Management 5, no. 2 (December 31, 2020): 201-220. Accessed February 8, 2021. http://journal.uinsgd.ac.id/index.php/isema.

Nursita, Dwi Indah. "Penerapan Blanded Learning Pada Siswa Sekolah Dasar: Sebagai Upaya Meningkatkan Kualitas Pembelajaran Di Masa Pandemi Covid ..." SALIMA: Jurnal Pendidikan Guru MI 1, no. 1 (2021): 1-12. http://ejurnal.staiattanwir.ac.id/index.php/jpgmi/article/view/52.

Setyaningsih, Kurnia Dwi, Karma Iswasta Eka, and Badarudin Badarudin. "Analisis Pelaksanaan Pembelajaran Jarak Jauh Di SD Negeri Karangrena 03.” Jurnal Riset Pendidikan Dasar (JRPD) 2, no. 1 (2021): 1-9.

Susilo, M. Joko. Kurikulum Tingkat Satuan Pendidikan. Yogyakarta: Pustaka Pelajar, 2007.

Yazid, Henri, and Neviyarni. "Pengaruh Pembelajaran Daring Terhadap Psikologi Siswa Akibat Covid-19." Jurnal Human Care 6, no. 1 (2021): 207-213.

Zaini, Faridatul Kibtiyah, Anwar Sa'dullah, and Muhammad Sulistiono. "Implementasi Hybrid Learning Dalam Pembelajaran Pendidikan Agama Islam Di SMAN 2 Malang." VICRATINA: Jurnal Pendidikan Islam 6, no. 4 (2021): 103-112. 